Classical Sculpture 


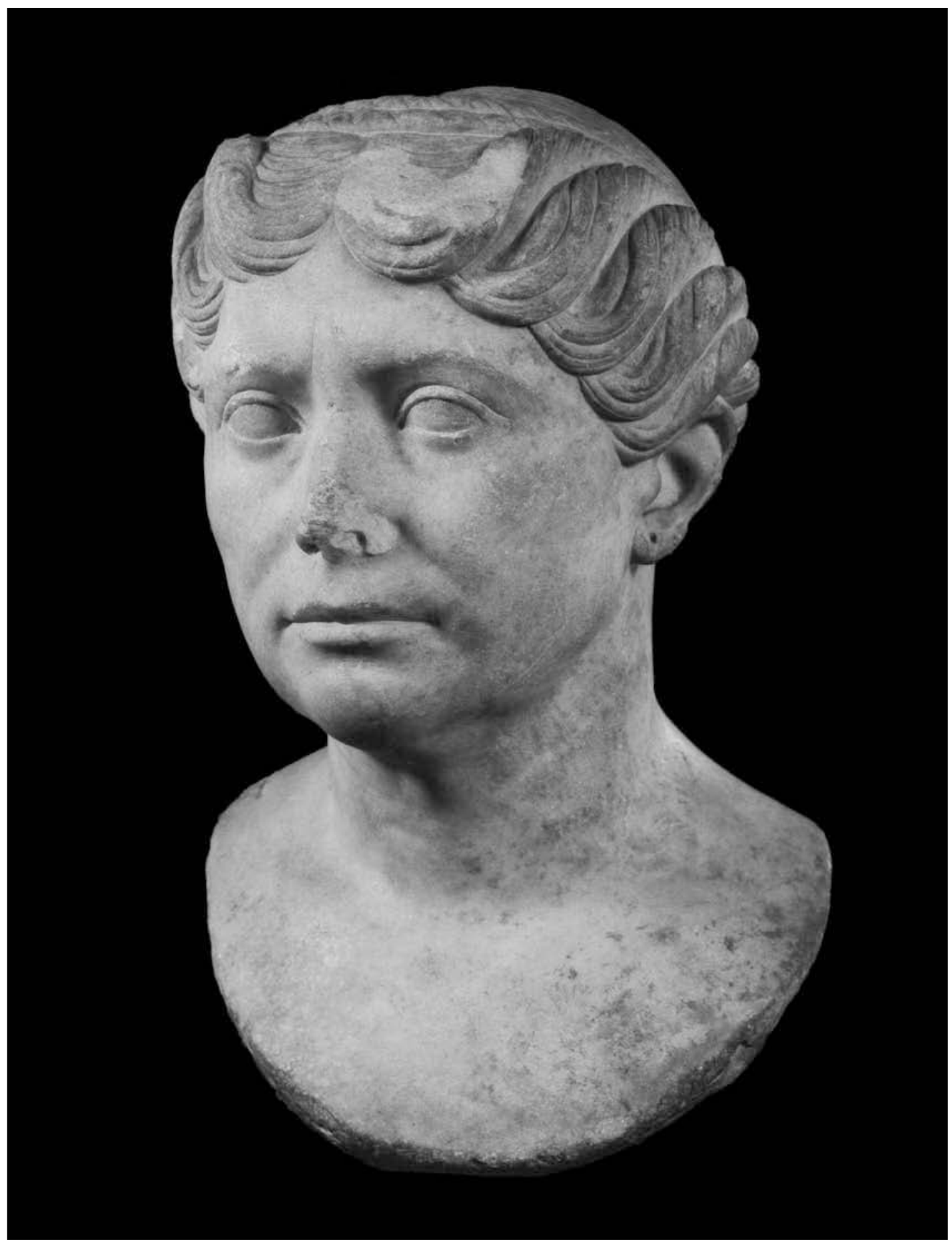

Frontispiece. Portrait of a middle-aged woman (102). 


\section{Classical Sculpture}

Catalogue of the Cypriot, Greek, and Roman Stone Sculpture in the University of Pennsylvania Museum of Archaeology and Anthropology

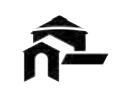

University of Pennsylvania Museum of Archaeology and Anthropology Philadelphia 


\section{Copyright (C) 2006 by University of Pennsylvania Museum of Archaeology and Anthropology}

3260 South Street, Philadelphia, PA 19104-6324

First Edition

All Rights Reserved

For Katy, Sarah, Lizzie, and David

LIBRARY OF CONGRESS CATALOGING-IN-PUBLICATION DATA

University of Pennsylvania. Museum of Archaeology and Anthropology.

Classical sculpture : catalogue of the Cypriot, Greek, and Roman stone sculpture in the University of Pennsylvania Museum of Archaeology and Anthropology / Irene Bald Romano.—-1st ed.

p. cm.

Includes bibliographical references and index.

ISBN-13: 978-1-931707-84-8 (hardcover : alk. paper)

ISBN-10: 1-931707-84-7 (hardcover : alk. paper)

1. Sculpture, Classical-Catalogs. 2. Sculpture, Cypriote-Catalogs. 3. Sculpture-Pennsylvania-Philadelphia—Catalogs.

4. University of Pennsylvania. Museum of Archaeology and Anthropology-Catalogs. I. Romano, Irene Bald. II. Title.

NB87.P45U555 2006

$733.3074-\mathrm{dc} 22$

2006001040

Publication of this book has been aided by a grant from the von Bothmer Publication Fund of the Archaeological Institute of America.

Financial support was also provided by The Samuel H. Kress Foundation and the American Hellenic Institute Foundation.

Printed in the USA on acid-free paper 